\title{
Perbandingan Anestesi Spinal Menggunakan Ropivakain Hiperbarik 13,5 mg dengan Ropivakain Isobarik 13,5 mg terhadap Mula dan Lama Kerja Blokade Sensorik
}

\author{
Hunter D. Nainggolan, ${ }^{1}$ Iwan Fuadi, ${ }^{2}$ Ike Sri Redjeki ${ }^{2}$ \\ ${ }^{1}$ Rumah Sakit Mitra Keluarga Tegal, ${ }^{2}$ Departemen Anestesiologi dan Terapi Intensif \\ Fakultas Kedokteran Universitas Padjadjaran/Rumah Sakit Dr. Hasan Sadikin Bandung
}

\begin{abstract}
Abstrak
Penyebaran obat anestesi lokal pada anestesi spinal terutama ditentukan oleh barisitas dan posisi. Penelitian ini bertujuan membandingkan mula dan lama kerja blokade sensorik antara anestesi spinal menggunakan ropivakain hiperbarik 13,5 mg dan ropivakain isobarik 13,5 mg. Penelitian dilakukan dengan uji acak terkontrol buta ganda mengikutsertakan 32 pasien usia 50-70 tahun, ASA I-II yang menjalani transurethral resection of prostate (TURP) dengan anestesi spinal di Rumah Sakit Dr. Hasan Sadikin Bandung pada AprilJuli 2012. Data hasil penelitian dianalisis menggunakan Uji Mann-Whitney dengan tingkat kepercayaan $95 \%$ dan dianggap bermakna bila $\mathrm{p}<0,05$. Hasil penelitian didapatkan mula kerja blokade sensorik pada ropivakain hiperbarik 5,00 (SB 1,03) menit lebih cepat secara bermakna dibandingkan dengan ropivakain isobarik 10,25 (SB 1,23) menit dan terdapat perbedaan lama kerja blokade sensorik secara bermakna, dengan lama kerja ropivakain hiperbarik adalah 89,38 (SB 5,12) menit dibandingkan dengan ropivakain isobarik 125,94 (SB 7,57) menit. Simpulan penelitian ini adalah anestesi spinal menggunakan ropivakain hiperbarik menghasilkan mula kerja blokade sensorik yang lebih cepat dan lama kerja blokade sensorik yang lebih pendek bila dibandingkan dengan ropivakain isobarik pada pasien yang menjalani operasi TURP.
\end{abstract}

Kata kunci: Anestesi spinal, barisitas, lama kerja, mula kerja, ropivakain, transurethral resection of prostate

\section{Comparison of Onset and Sensory Blockade Duration of Spinal Anesthesia between $13.5 \mathrm{mg}$ Hyperbaric Ropivacaine and $13.5 \mathrm{mg}$ Isobaric Ropivacaine}

\begin{abstract}
The spread of the local anesthetic drug in spinal anesthesia is primarily determined by baricity and position. The aim of this study was to compare the onset and duration of sensoric blockade in spinal anaesthesia using $13.5 \mathrm{mg}$ hyperbaric ropivacaine and $13.5 \mathrm{mg}$ isobaric ropivacaine. This was a double blind randomized trial involving 32 patients aged between 50-70 years with ASA I-II whom underwent TURP surgery with spinal anesthesia at Dr. Hasan Sadikin Hospital Bandung within April-July 2012. Data was analyzed using Mann-Whitney Test with level of confidence $95 \%$ and $p<0.05$ was significant. The result showed that onset of sensory blockade in hyperbaric ropivacaine 5.00 (SB 1.03) minutes was significantly faster compared to isobaric ropivacaine 10.25 (SB 1,23) minutes and there was significant difference on sensory blockade duration, where hyperbaric ropivacaine 89.38 (SB 5.12) minutes was shorter than isobaric ropivacaine 125.94 (SB 7.57) minutes. The conclusions of this study shown spinal anesthesia using hyperbaric ropivacaine produced faster onset and shorter duration of sensory block compared to isobaric ropivacaine in TURP surgery.
\end{abstract}

Key words: Baricity, duration, onset, spinal anesthesia, ropivacaine, transurethral resection of prostate

Korespondensi: Hunter D. Nainggolan, dr., SpAn, Rumah Sakit Mitra Keluarga Tegal, Jl. Sipelem, Kemandungan, TegalJawa Tengah, Telp. (0283) 340902, Mobile 081316494804, Email hunternainggolan@yahoo.com 


\section{Pendahuluan}

Perkembangan ilmu pengetahuan mendorong pelaksanaan pelayanan kesehatan yang lebih efektif serta ekonomis dibandingkan dengan cara yang sudah lazim dikerjakan. Termasuk dalam hal ini adalah pemilihan teknik operasi, anestesia, dan juga obat-obat yang digunakan. Pada saat ini, dokter anestesi dituntut untuk memberikan pelayanan optimal, bukan hanya untuk memfasilitasi pembedahan tetapi juga harus mampu memberikan rasa nyaman pada pasien yang menjalani pembedahan. ${ }^{1}$

Sampai sekarang, berbagai teknik anestesi telah dikembangkan agar dapat memfasilitasi tindakan operasi. Akhir-akhir ini, penggunaan anestesiregional menjadisemakinberkembang dan meluas. Anestesi spinal merupakan teknik yang mudah dilakukan, dengan kedalaman dan kecepatan blokade saraf melalui penyuntikan dosis kecil larutan anestetika lokal ke dalam ruang subaraknoid. ${ }^{2}$ Banyak keuntungan yang ditawarkan teknik ini, antara lain biaya yang relatif lebih murah, efek sistemik relatif kecil, analgesia adekuat, dan kemampuan mencegah respons stres dengan lebih sempurna. Teknik anestesi regional dengan cara pemilihan obat anestesia lokal yang ideal sangat menentukan untuk mendapatkan hasil yang memuaskan dan aman. ${ }^{3}$

Anestesi spinal merupakan teknik anestesi regional yang dihasilkan dengan menghambat saraf spinal di dalam ruang subaraknoid oleh zat-zat anestetik lokal. Teknik anestesia spinal banyak digunakan karena merupakan teknik yang sederhana, efektif, aman terhadap sistem saraf, tidak menyebabkan konsentrasi plasma yang berbahaya, memberikan tingkat analgesia yang kuat, pasien tetap sadar, relaksasi otot cukup, perdarahan luka operasi lebih sedikit, risiko aspirasi pasien dengan lambung penuh lebih kecil, dan juga pemulihan fungsi saluran pencernaan lebih cepat. ${ }^{2-4}$

Obat anestesia lokal yang ideal mempunyai mula kerja yang cepat, durasi kerja dan juga tinggi blokade dapat diperkirakan sehingga dapat disesuaikan dengan lama operasi, tidak neurotoksik, serta pemulihan blokade motorik pascaoperasi yang cepat sehingga mobilisasi dapat lebih cepat dilakukan. ${ }^{4,5}$ Beberapa faktor yang dianggap akan memengaruhi penyebaran obat anestesia lokal antara lain karakteristik obat anestesia lokal (barisitas, dosis, volume, konsentrasi, dan juga zat aditif), teknik (posisi tubuh, tempat penyuntikan, barbotase, serta tipe jarum), dan juga karakteristik pasien (usia, tinggi, berat badan, tekanan intraabdomen, kehamilan, dan anatomi dari tulang belakang). Faktor yang dianggap paling berperan adalah barisitas dan juga posisi tubuh. Barisitas obat sangat menentukan penyebaran obat anestesi lokal dan ketinggian blokade. ${ }^{4,5}$

Barisitas ialah rasio densitas obat anestesia lokal terhadap densitas cairan serebrospinal (1,003-1,009). Densitas tersebut didefinisikan sebagai berat dalam gram dari $1 \mathrm{~mL}$ cairan pada temperatur tertentu. ${ }^{4-6}$ Densitas cairan serebrospinal tidak seragam, tetapi bervariasi bergantungpada usia,jenis kelamin, kehamilan, dan juga penyakit penyerta tertentu. Densitas cairan serebrospinal lebih rendah pada wanita dibandingkan dengan laki-laki, ${ }^{7}$ pada wanita hamil dibandingkan dengan tidak hamil, ${ }^{8}$ dan wanita premenoupause dibandingkan dengan wanita pascamenopause dan pria. ${ }^{9}$ Secara teori perbedaan ini akan menyebabkan perubahan barisitas obat anestesia lokal pada kelompok pasien yang berbeda, akan tetapi perbedaan tersebut tidak terlalu besar dan mungkin tidak bermakna secara klinis. ${ }^{10}$

Obat anestesi lokal disebut hipobarik bila mempunyai densitas \pm 3 (tiga) standar deviasi (SD) di bawah densitas cairan serebrospinal. ${ }^{6,10}$ Penyuntikan obat jenis hipobarik pada posisi duduk akan menyebar ke arah sefalad. Pada posisi miring (posisi lateral) atau berbaring penyebaran obat hipobarik sangat ditentukan oleh bentuk vertebra dan penyebaran ke arah kaudal. ${ }^{4,5,10}$

Anestetik lokal hiperbarik adalah obat yang memiliki densitas \pm 3 (tiga) standar deviasi (SD) di atas densitas dari cairan serebrospinalis. ${ }^{6,10}$ Hal ini menyebabkan distribusi obat anestesia lokal jenis hiperbarik akan sangat dipengaruhi oleh posisi pasien yang berhubungan dengan gaya gravitasi. Pada saat penyuntikan dengan posisi duduk, obat anestesia lokal hiperbarik tersebut menyebar ke daerah kaudal, apabila 
sesaat setelah dilakukan penyuntikan, posisi pasien berbaring dengan kepala ke arah bawah maka obat anestesia lokal akan menyebar ke arah sefalad, namun pada posisi miring (posisi lateral) obat anestesia lokal hiperbarik dapat menyebar ke arah sefalad. ${ }^{11,12}$

Obat anestesia lokal isobarik adalah obat lokal anestesia yang mempunyai densitas yang sama dengan cairan serebrospinalis dan tidak ada efek gaya gravitasi atau posisi tubuh. ${ }^{4,5,10}$ Obat anestesia lokal hiperbarik menyebabkan pemendekan waktu blokade sensorik dan juga motorik jika dibandingkan dengan isobarik. Namun, obat anestesi lokal hiperbarik mampu menghasilkan mula kerja dan juga pemulihan lebih cepat, penyebaran yang lebih luas, serta tingkat keberhasilan lebih dapat diandalkan jika dibandingkan dengan isobarik..$^{12-16}$

Anestesia spinal merupakan suatu teknik anestesia pilihan yang digunakan pada operasi transurethral resection of prostate (TURP) karena memiliki beberapa keuntungan, yaitu dapat segera diketahui bila terjadi komplikasi, seperti terjadinya sindrom TURP (intoksikasi air), kelebihan cairan, perforasi pada kandung kemih terutama ke area retroperitoneal, serta perdarahan. Hal ini akan mudah dikenali bila pasien sadar selama operasi, yaitu pada pasien yang menjalani anestesia regional spinal atau epidural. ${ }^{17,18}$ Transurethral resection of prostate (TURP) merupakan pembedahan yang paling sering dipergunakan dalam penatalaksanaan pasien dengan hipertropi prostat yang jinak (benign prostatic hypertrophy) dan simtomatik yang tidak terdapat perbaikan dengan terapi medikamentosa. ${ }^{19}$

Bupivakain hiperbarik 0,5\% ialah golongan obat anestesia lokal yang sering dipergunakan pada tindakan TURP. Penggunaan bupivakain mempunyai beberapa efek samping, antara lain hemodinamik kurang stabil serta peningkatan blokade motorik. . $^{17,18,20,21}$ Obat anestesia lokal semakin berkembang dengan ditemukan jenis ropivakain (Naropin ${ }^{\circledR}$ ) turunan dari senyawa golongan amida. ${ }^{22}$ Ropivakain diperkenalkan pada tahun 1997 sebagai alternatif yang lebih aman dari bupivakain dengan lama kerja lebih singkat terutama pada blokade motorik.

Efek analgesia pada ropivakain sebanding dengan bupivakain apabila dipakai pada dosis yang sebanding, dengan batas keamanan yang lebih besar sehingga dapat digunakan dengan konsentrasi lebih tinggi dan dosis lebih besar apabila dibandingkan dengan bupivakain. Efek blok motorik yang dihasilkan ropivakain lebih ringan, namun memiliki efek analgesia yang adekuat. ${ }^{22}$ Dosis anestesi lokal ropivakain pada anestesia spinal untuk operasi TURP (daerah abdomen bagian bawah) adalah 12-16 mg. ${ }^{23}$

Penelitian yang dilakukan terhadap pasien yang menjalani prosedur TURP dengan teknik anestesia spinal dilaporkan bahwa ropivakain hiperbarik dosis $15 \mathrm{mg}$ memberikan beberapa keuntungan, antara lain efek blok saraf spinal yang lebih baik, mula kerja lebih cepat, durasi kerja lebih pendek, dan pemulihan lebih cepat dibandingkan dengan ropivakain isobarik 15 mg. ${ }^{24,25}$

Penelitian ini bertujuan untuk mengetahui perbandingan antara anestesia spinal dengan menggunakan ropivakain hiperbarik 13,5 mg dan ropivakain isobarik 13,5 mg terhadap mula serta lama kerja blokade sensorik pada pasien yang menjalani operasi TURP.

\section{Subjek dan Metode}

Penelitian ini dilakukan setelah mendapatkan persetujuan Komite Etik Penelitian Kesehatan Fakultas Kedokteran Universitas Padjadjaran/ Rumah Sakit Dr. Hasan Sadikin Bandung. Jumlah sampel pada penelitian ini ditentukan berdasarkan pada perbedaan 2 (dua) proporsi efektivitas dari dua tindakan, dengan memilih tingkat kepercayaan $(\alpha) 95 \%$, dengan besarnya uji kekuatan 95\%, didapatkan jumlah sampel yang dibutuhkan adalah 32 sampel.

Kriteria inklusi, adalah pasien hipertrofi prostat yang menjalani operasi TURP elektif menggunakan teknik anestesia spinal, berusia 50-70 tahun, status fisik American Sosiety of Anesthesia (ASA) I-II, serta operasi kurang dari 90 menit. Kriteria eksklusi, adalah terdapat kontraindikasi absolut dan relatif penggunaan anestesia spinal, riwayat alergi obat-obatan yang digunakan dalam penelitian, tinggi badan pasien $\leq 155 \mathrm{~cm}$ atau $\geq 175 \mathrm{~cm}$ dan obesitas dengan indeks massa tubuh (IMT) $>30$. Kriteria 
pengeluaran pada penelitian ini, yaitu bila efek obat spinal habis sebelum operasi selesai dan mendapatkan penambahan obat anestesi lain, serta terjadi sindrom TURP saat operasi.

Subjek ialah pasien-pasien yang menjalani operasi TURP dengan teknik anestesia spinal di Rumah Sakit Dr. Hasan Sadikin Bandung dari bulan April 2011 sampai dengan bulan Juli 2012. Pasien dibagi dalam dua kelompok, yaitu kelompok A mendapatkan spinal dengan ropivakain $0,75 \%$ isobarik dosis $13,5 \mathrm{mg}(1,8$ $\mathrm{mL}$ ) ditambahkan dekstrosa 40\% 0,5 mL, dan kelompok B mendapatkan ropivakain 0,75\% isobarik dosis 13,5 mg (1,8 mL) ditambahkan $\mathrm{NaCl}$ 0,9\% sebanyak 0,5 mL. Setiap kelompok terdiri atas 16 subjek penelitian, kemudian dilakukan uji dengan cara acak terkontrol buta ganda (double blind randomized controlled trial).

Semua pasien dipuasakan selama 6 jam sebelum operasi dari makanan padat, 2 jam terhadap air putih, dan pasien tidak diberikan obat-obatan premedikasi. Selanjutnya, secara acak pasien dibagi menjadi 2 (dua) kelompok, setiap kelompok terdiri atas 16 orang pasien. Kelompok A merupakan kelompok ropivakain hiperbarik 13,5 mg, serta kelompok B adalah ropivakain isobarik $13,5 \mathrm{mg}$. Alat-alat pantau dipasang pada tubuh pasien dan dicatat data tekanan darah, laju nadi, dan saturasi oksigen sebagai data dasar, kemudian dipasang infus dan diberi cairan RL yang sudah dihangatkan $10 \mathrm{~mL} / \mathrm{kgBB}$ selama 15 menit. Sesudah itu dilakukan penyuntikan anestesia spinal pada posisi duduk membungkuk mempergunakan jarum spinal Quincke no. 27G yang ditusukkan di $\mathrm{L}_{4-5}$ dengan bevel jarum spinal menghadap ke lateral.

Saat didapatkan aliran cairan serebrospinal yang jernih, bevel jarum diputar ke arah kepala (dengan patokan memutar pengunci mandrain ke arah kepala), kemudian larutan anestetik lokal disuntikkan dengan kecepatan $\pm 10-15$ detik setelah dilakukan barbotase sebelumnya. Setelah itu, pasien dibaringkan pada posisi datar, terlentang dengan satu bantal di kepala. Oksigen diberikan pada pasien dengan binasal kanul 2-3 L/menit.
Tes pinprickdilakukansetiap 2 menitdengan menggunakan jarum 25G sampai didapatkan kriteria Hollmens $\geq 2$ pada daerah dermatom $\mathrm{T}_{10}$ untuk menilai mula kerja blokade sensorik, kemudian kembali dilakukan uji pinprick dari $\mathrm{T}_{10}$ ke arah sefalad dengan kriteria Hollmens $\geq 2$ sampai didapatkan level blokade sensorik pada dermatom tertinggi. Mula kerja blokade motorik juga dinilai sampai mencapai skala Bromage 3. Pasien kemudian diletakkan dalam posisi litotomi dan operasi dimulai.

Waktu yang dibutuhkan untuk regresi dari blokade sensorik dermatom tertinggi sampai dermatom $\mathrm{T}_{10}$ dengan kriteria Hollmens $<2$ merupakan penilaian dari lama kerja blokade sensorik. Lama kerja blokade sensorik dinilai setiap 5 menit sampai didapatkan dermatom $\mathrm{T}_{10}$. Lama kerja blokade motorik dinilai setelah operasi selesai pada posisi pasien terlentang.

Tekanan darah, laju nadi, dan juga saturasi oksigen perifer $\left(\mathrm{SpO}_{2}\right)$ diukur setiap 2,5 menit setelah suntikan selama 30 menit pertama, tiap 5 menit pada saat 30 menit kedua sampai selesainya operasi. Selama operasi dilakukan, kejadian hipotensi (penurunan tekanan darah $\geq 20 \%$ dari nilai tekanan darah awal atau sistol $\leq 90 \mathrm{mmHg}$ ), bradikardia (laju nadi $\leq 50 \mathrm{x}$ / menit) dicatat. Bila terjadi hipotensi, pasien diberikan efedrin 5-10 mg intravena dan bila bradikardia diberikan obat sulfas atropin 0,5 mg intravena. Selama operasi berlangsung diberikan cairan 1-1,5 mL/kgBB menggunakan cairan kristaloid, untuk perdarahan diganti dengan kristaloid, koloid, atau darah. Selama operasi berlangsung pasien diberikan cairan infus hangat serta selimut hangat. Bila pasien menggigil diberikan petidin $25 \mathrm{mg}$ intravena. Jika terjadi penurunan saturasi diberi oksigen $100 \%$ dengan sungkup muka.

Sebelum analisis univariabel dan bivariabel, dilakukan terlebih dahulu uji normalitas data numerik untuk melihat distribusi data blokade sensorik menggunakan Uji Shapiro Wilks untuk besar sampel kurang dari 50 orang. Analisis univariabel bertujuan untuk menggambarkan karakteristik subjek penelitian, mula kerja, dan juga lama kerja blokade sensorik. Apabila data tidak berdistribusi secara normal maka data 
Tabel 1 Perbandingan Karakteristik Umum Subjek Penelitian

\begin{tabular}{|c|c|c|c|c|c|c|c|}
\hline \multirow{3}{*}{ Karakteristik } & \multicolumn{6}{|c|}{ Ropivakain } & \multirow{3}{*}{ Nilai p } \\
\hline & \multicolumn{3}{|c|}{ Hiperbarik $(n=16)$} & \multicolumn{2}{|c|}{ Isobarik $(\mathrm{n}=16)$} & \multirow[b]{2}{*}{ SB } & \\
\hline & $\mathbf{n}$ & Rata-rata & SB & $\mathbf{n}$ & Rata-rata & & \\
\hline Usia (tahun) & & 88,4 & 4,0 & & 6,3 & 4,4 & $\left.0,431^{*}\right)$ \\
\hline Berat badan $(\mathrm{kg})$ & & 61,6 & 7,5 & & 57,9 & 7,7 & $\left.0,174^{*}\right)$ \\
\hline Tinggi badan $(\mathrm{cm})$ & & 164,3 & 5,1 & & 163,0 & 4,0 & $\left.0,426^{*}\right)$ \\
\hline IMT $\left(\mathrm{kg} / \mathrm{m}^{2}\right)$ & & 22,5 & 2,4 & & 22,4 & 2,7 & $\left.0,348^{*}\right)$ \\
\hline Pendidikan & & & & & & & $\left.0,662^{* *}\right)$ \\
\hline SD & 3 & & & 2 & & & \\
\hline SMP & 5 & & & 5 & & & \\
\hline SMA & 8 & & & 8 & & & \\
\hline S-1 & 0 & & & 1 & & & \\
\hline Lama operasi (menit) & & 67,06 & 7,8 & & 70,6 & 7,1 & $\left.0,195^{*}\right)$ \\
\hline ASA & & & & & & & $\left.0,500^{* *}\right)$ \\
\hline I & 1 & & & 2 & & & \\
\hline II & 15 & & 14 & & & & \\
\hline
\end{tabular}

Keterangan: *) uji-t **) uji chi-kuadrat

disajikan dalam median dan nilai maksimum serta minimum (rentang), sedangkan apabila data berdistribusi normal maka data disajikan dalam ukuran rata-rata dan standar deviasi.

Analisis bivariabel dipakai untuk menguji perbandingan pengaruh ropivakain hiperbarik $13,5 \mathrm{mg}$ dengan ropivakain isobarik $13,5 \mathrm{mg}$ terhadap mula kerja, untuk lama kerja blokade sensorik digunakan uji-t bila data berdistribusi normal dan Uji Mann Whitney bila data tidak berdistribusi normal. Analisis data dilakukan dengan mempergunakan program statistical product and servise solution (SPSS) for windows versi 17.0 dengan tingkat kepercayaan 95\% dan dianggap bermakna bila $\mathrm{p} \leq 0,05$.

\section{Hasil}

Hasil analisis statistika mempergunakan uji-t dengan derajat kepercayaan 95\%, didapatkan bahwa karakteristik umum subjek penelitian berdasarkan usia, berat badan, tinggi badan, IMT, pendidikan, lama operasi, dan ASA pada pasien yang menjalani operasi elektif TURP mempergunakan ropivakain hiperbarik 13,5 mg maupun pada ropivakain isobarik $13,5 \mathrm{mg}$ dengan teknik anestesia spinal tidak terdapat perbedaan bermakna ( $p>0,05$; Tabel 1$)$.

Tabel 2 Perbandingan Mula Kerja Blokade Sensorik

\begin{tabular}{lccc}
\hline \multirow{2}{*}{ Mula Kerja Sensorik } & \multicolumn{2}{c}{ Ropivakain } & \multirow{2}{*}{ Nilai p } \\
\cline { 2 - 3 } & Hiperbarik (n=16) & Isobarik (n=16) & \\
\hline Rata-rata (SB) & $5,0(1,03)$ & $10,3(1,23)$ & $<\mathbf{0 , 0 0 1}$ \\
Median & 5 & 10 & \\
Minimum & 4 & 8 & \\
Maksimum & 6 & 12 & \\
\hline
\end{tabular}

Keterangan: *) Uji Mann Whitney 


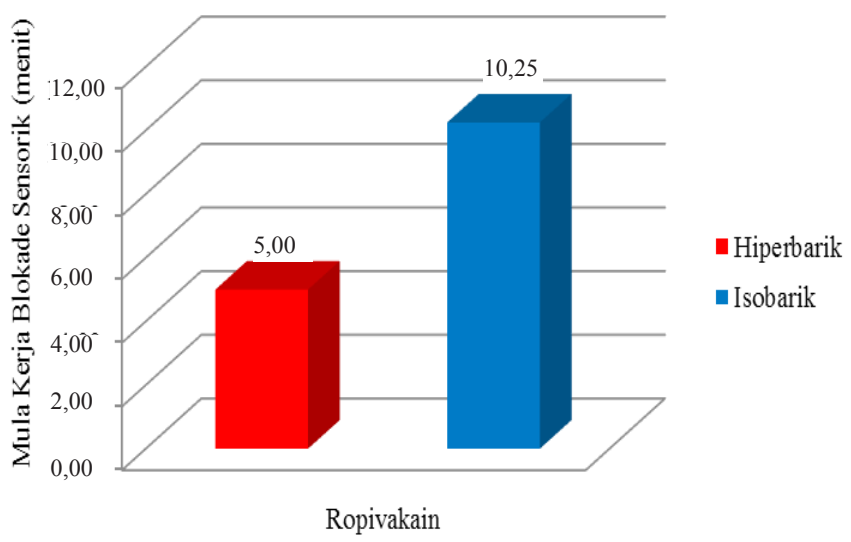

Gambar 1 Perbandingan Mula Kerja Blokade Sensorik antara Ropivakain Hiperbarik dan Isobarik

Mula kerja blok sensorik rata-rata pada kelompok ropivakain hiperbarik 13,5 mg lebih cepatdibandingkan dengan ropivakain isobarik $13,5 \mathrm{mg}$ (5 vs 10,3 menit), berdasarkan hasil Uji Mann Whitney pada derajat kepercayaan 95\% menunjukkan perbedaan yang bermakna ( $\mathrm{p}<0,001$; Tabel 2; Gambar 1).

Lama blokade sensorik rata-rata kelompok ropivakain hiperbarik 13,5 mg adalah 89,4 menit, sedangkan pada kelompok ropivakain isobarik 13,5 mg adalah selama 125,9 menit. Berdasarkan hasil uji statistika menggunakan Uji Mann Whitney dengan derajat kepercayaan 95\%, menunjukkan bahwa perbedaan tersebut bermakna ( $p<0,001$; Tabel 3; Gambar 1).

Mula kerja blokade motorik rata-rata pada kelompok ropivakain hiperbarik dosis 13,5 mg adalah 8,9 menit, sedangkan pada kelompok ropivakain isobarik 13,5 mg adalah 13,9 menit. Berdasarkan hasil uji statistika menggunakan

Tabel 3 Perbandingan Lama Kerja Blokade Sensorik

\begin{tabular}{lccc}
\hline \multirow{2}{*}{$\begin{array}{c}\text { Lama Kerja Sensorik } \\
\text { (menit) }\end{array}$} & \multicolumn{2}{c}{ Ropivakain } & \multirow{2}{*}{ Nilai p } \\
\cline { 2 - 3 } & Hiperbarik (n=18) & Isobarik (n=18) & \\
\hline Rata-rata (SB) & $89,4(5,1)$ & $125,9(7,6)$ & $<0,001$ \\
Median & 90 & 125 & \\
Minimum & 80 & 120 & \\
Maksimum & 95 & 145 & \\
\hline
\end{tabular}

Keterangan: *j Uji Mann-Whitney

Tabel 4 Perbandingan Mula Kerja Blokade Motorik

\begin{tabular}{lccc}
\hline \multirow{2}{*}{$\begin{array}{c}\text { Mula Kerja Motorik } \\
\text { (menit) }\end{array}$} & \multicolumn{2}{c}{ Ropivakain } & Nilai p \\
\cline { 2 - 3 } & Hiperbarik (n=16) & Isobarik (n=16) & $<0, \mathbf{0 0 1}$ \\
Rata-rata (SB) & $8,9(1,0)$ & $13,9(1,1)$ & \\
Median & 8 & 14 \\
Minimum & 8 & 12 \\
Maksimum & 10 & 16 \\
\hline
\end{tabular}

Keterangan: *j Uji Mann-Whitney 


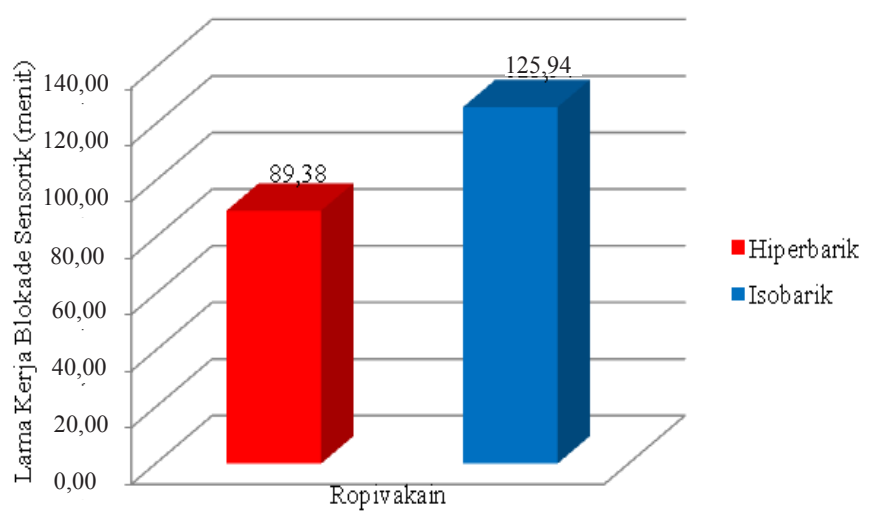

Gambar 2 Perbandingan Lama Kerja Blokade Sensorik antara Ropivakain Hiperbarik dan Isobarik

Uji Mann Whitney dengan derajat kepercayaan 95\%, terdapat perbedaan bermakna $(\mathrm{p}<0,001$; Tabel 4).

Lama blokade motorik rata-rata kelompok ropivakain hiperbarik 13,5 mg adalah 116,3 menit, sedangkan pada kelompok ropivakain isobarik 13,5 mg adalah selama 159,4 menit. Berdasarkan hasil uji statistika menggunakan Uji Mann Whitney pada derajat kepercayaan
$95 \%$, terdapat perbedaan bermakna $(\mathrm{p}<0,001$; Tabel 5).

Tinggi blokadesensorikrata-rata kelompok ropivakain hiperbarik 13,5 mg adalah pada level T4 sebanyak 7 pasien dan pada level T6 sebanyak 8 orang, sedangkan pada kelompok ropivakain isobarik 13,5 mg adalah level T8 sebanyak 10 pasien. Berdasarkan hasil uji statistika chi-kuadrat menunjukkan ketinggian

Tabel 5 Perbandingan Lama Kerja Blokade Motorik

\begin{tabular}{lccc}
\hline \multirow{2}{*}{$\begin{array}{c}\text { Lama Kerja Motorik } \\
\text { (menit) }\end{array}$} & \multicolumn{2}{c}{ Ropivakain } & \multirow{2}{*}{ Nilai p } \\
\cline { 2 - 3 } & Hiperbarik (n=16) & Isobarik (n=16) & \\
\hline Rata-rata (SB) & $116,3(10,3)$ & $159,4(8,5)$ & $<0,001$ \\
Median & 115 & 160 & \\
Minimum & 100 & 150 & \\
Maksimum & 130 & 180 & \\
\hline
\end{tabular}

Keterangan: *j Uji Mann-Whitney

Tabel 6 Perbandingan Tinggi Blokade Sensorik

\begin{tabular}{cccc}
\hline \multirow{2}{*}{ Tinggi Blokade Sensorik } & \multicolumn{2}{c}{ Ropivakain $\mathbf{0 , 7 5 \%}$} & \multirow{2}{*}{ Nilai p } \\
\cline { 2 - 3 } & Hiperbarik (n=16) & Isobarik (n=16) & $<\mathbf{0 , 0 0 1}$ \\
T4 & 7 & 0 & \\
T5 & 1 & 0 \\
T6 & 8 & 2 \\
T7 & 0 & 4 \\
T8 & 0 & 10 \\
\hline
\end{tabular}

Keterangan: *) uji chi-kuadrat 
blokade sensorik pada ropivakain hiperbarik $13,5 \mathrm{mg}$ berbeda secara bermakna $(\mathrm{p}<0,001$; Tabel 6).

Pada penelitian ini, petidin akan diberikan apabila subjek penelitian mengalami menggigil derajat $>1$ sesuai skala Tsai dan Chu. Selama operasi berlangsung, pada kedua kelompok perlakuan tidak didapatkan pasien menggigil dengan derajat $>1$.

\section{Pembahasan}

Anestesia spinal merupakan salah satu teknik pilihan untuk tindakan operasi TURP karena menawarkan banyak keuntungan, salah satu yang terpenting adalah pasien selalu dalam keadaan sadar sehingga dapat dengan cepat diketahui bila terjadi komplikasi. ${ }^{17,18}$ Berbagai inovasi terhadap teknik dan juga obat-obatan dikembangkan untuk menyempurnakan hasil dan mengurangi kelemahan yang ada sehingga diperoleh anestesia spinal yang ideal, antara lain dengan mengubah barisitas obat anestesia lokal.

Bupivakain hiperbarik 0,5\% merupakan obat anestesia lokal yang sering dipergunakan pada operasi TURP, tetapi bupivakain memiliki beberapa efek samping seperti hemodinamik yang kurang stabil dan meningkatnya blokade motorik. ${ }^{17,18,20,21}$ Obat anestesia lokal semakin berkembang dengan ditemukannya ropivakain (Naropin $®$ ) sebagai turunan dari senyawa golongan amida. ${ }^{22}$

Ropivakain merupakan obat alternatif yang lebih aman dibandingkan dengan bupivakain dengan lama kerja yang lebih singkat terutama pada blok motorik. Efek analgesia ropivakain sebanding dengan bupivakain apabila dipakai pada dosis sebanding, dengan batas keamanan yang lebih besar sehingga dapat dipakai dengan konsentrasi lebih tinggi dan dosis lebih besar dibandingkan dengan bupivakain. Efek blok motorik yang dihasilkan oleh ropivakain lebih ringan dengan efek analgesia yang adekuat. ${ }^{22}$

Penelitian ini dilakukan terhadap 32 orang yang dibagi dalam 2 kelompok perlakuan, yaitu ropivakain hiperbarik 13,5 mg (kelompok A) dan ropivakain isobarik 13,5 mg (kelompok B), masing-masingsebanyak 16 oranguntuk setiap kelompoknya. Berdasarkan data karakteristik umum pasien (Tabel 1), pada kedua kelompok perlakuan tidak menunjukkan perbedaan yang bermakna dalam hal usia, berat badan, tinggi badan, IMT, pendidikan, lama operasi, serta ASA. Hal ini menunjukkan bahwa sampel yang diambil dalam penelitian ini homogen secara statistik $(p>0,05)$, sehingga kedua kelompok layak untuk diperbandingkan.

Mula kerja blokade sensorik anestesia spinal mempergunakan ropivakain hiperbarik, lebih cepat dibandingkan dengan ropivakain isobarik, yaitu 5,00 (SB 1,03) menit vs 10,25 (SB 1,23 ) menit dan secara statistik menunjukkan perbedaan bermakna $(p<0,001)$. Mula kerja blokade sensorik pada kelompok ropivakain hiperbarik lebih cepat daripada kelompok ropivakain isobarik, hal tersebut disebabkan ropivakain hiperbarik mempunyai barisitas lebih besar $(1,02970)$ apabila dibandingkan dengan barisitas cairan serebrospinal $(1,003-$ 1,009). Keadaan tersebut adalah sebagai akibat distribusi ropivakain hiperbarik yang sangat dipengaruhi posisi pasien yang berhubungan dengan gravitasi, sehingga perubahan posisi dari posisi duduk ke posisi terlentang segera setelah penyuntikan ropivakain hiperbarik, menyebabkan ropivakain hiperbarik menyebar lebih cepat ke arah sefalad mengikuti lekukan kolumna vertebralis. ${ }^{11,12}$

Pengaruh gaya gravitasi pada pergerakan larutan anestetik lokal hiperbarik berlangsung sampai dengan semua larutan anestetik lokal tersebut terdilusi dalam larutan serebrospinal sehingga larutan akan menjadi isotonis. Pada kondisi teresebut, anestetik lokal tidak akan memberi respons terhadap perubahan posisi yang berhubungan dengan gravitasi, keadaan ini disebut dengan keadaan terfiksasi. Waktu yang diperlukan untuk terjadinya keadaan ini masih banyak diteliti. Waktu yang dibutuhkan agar tidak terjadi lagi respons anestetik lokal terhadap perubahan posisi tubuh pasien ialah 20 sampai 30 menit. ${ }^{11,12,26}$

Pada penelitian ini didapatkan lama kerja blokade sensorik lebih pendek pada kelompok ropivakain hiperbarik dibandingkan dengan kelompok ropivakain isobarik, yaitu 89,38 
(SB 5,12) menit vs 125,94 (SB 7,57) menit dan secara statistik menunjukkan perbedaan bermakna $(p<0,001)$. Hal tersebut disebabkan ketinggian blokade sensorik yang cenderung lebih tinggi pada ropivakain hiperbarik akan menyebabkan regresi (penurunan blokade) yang lebih cepat.

Penyebaran obat anestesi lokal yang lebih ke arah sefalad akan menghasilkan konsentrasi obat lebih rendah dalam cairan serebrospinal dan jaringan saraf, sehingga konsentrasi obat akan cepat berkurang di bawah konsentrasi minimum efektif obat sehingga pasien akan cepat merasa nyeri. ${ }^{4}$

Penyebaran anestetik yang terkonsentrasi di tempat penyuntikan seperti pada ropivakain isobarik menyebabkan konsentrasi obat yang relatif tinggi dalam cairan serebrospinal dan jaringan saraf sehingga mengakibatkan waktu yang lebih panjang untuk turun di bawah konsentrasi minimum efektif, dengan demikian lama kerja blokade sensorik pada ropivakain isobarik lebih panjang dibandingkan dengan ropivakain hiperbarik. ${ }^{4}$

\section{Simpulan}

Teknik anestesia spinal dengan menggunakan ropivakain hiperbarik 13,5 mg menghasilkan mula kerja blokade sensorik yang lebih cepat serta lama kerja blokade sensorik yang lebih pendek bila dibandingkan dengan ropivakain isobarik $13,5 \mathrm{mg}$ pada pasien yang menjalani operasi TURP.

\section{Daftar Pustaka}

1. Macario A, Weinger M, Carney S, Kim A. Which clinical anesthesia outcome are important to avoid? The perspective of patients. Anesth Analg. 1999;89(3):652-8.

2. Cianni SD, Rossi M, Casati A, Cocco C, Fanelli G. Spinal anesthesia: an evergreen technique. Acta Biomed. 2008;79:9-17.

3. Duke J. Anesthesia secrets. Edisi ke-3. Philadelphia: Mosby-Elsevier; 2006

4. Bernards CM. Epidural and spinal anesthesia. Dalam: Barash PG, Cullen
BF, Stoelting RK, penyunting. Clinical anesthesia. Edisi ke-5. Philadelphia: Lippincott William and Wilkins Co; 2006. hlm. 691-717.

5. Kleinmann W, Mikhail M. Clinical anesthesiology. Edisi ke-4. New York: McGraw-Hill Co; 2002.

6. McLeod G.A. Density of spinal anaesthetic solutions of bupivacaine, levobupivacaine, and ropivacaine with and without dextrose. Br J Anesth. 2004;92(4):547-51.

7. Schiffer E, Van Gessel E, Gamulin Z. Influence of sex on cerebrospinal fluid density in adult. Br J Anesth. 1999;83: 943-53.

8. Richardson MG, Wissler RN. Density of lumbar cerebrospinal fluid in pregnant and non pregnant humans. Anaesthesiology. 1996;85:326-30.

9. Lui ACP, Polis TZ, Cicutti NJ. Densities of cerebrospinal fluid and spinal anaesthesic solution in surgical patient at body temperature. Can J Anaesth. 1998;45: 297-303.

10. Connoly C, Wildsmith JA. Intrathecal drug spread. Can J Anaesth. 1998;45:289-92.

11. Berde CB, Strichartz GR. Local anesthetics. Dalam: Miller RD, penyunting. Miller's anesthesia. Edisi ke-7. Philadelphia: Elsevier Churchil Livingstone; 2010. hlm. 913-39.

12. Hendarjana P, As'at HM, Dachlan MR. Perbandingan mula kerja, masa kerja dan masa pulih antara ropivacaine plain $15 \mathrm{mg}$ dan ropivacaine hiperbarik $15 \mathrm{mg}$ pada analgesia spinal bedah sesar dengan posisi lateral dekubitus [tesis]. Jakarta: Universitas Indonesia; 2004.

13. Fettes PDW, Hocking G, Peterson MK, Lucjk JF, Wildsmith JA. Comparison of plain and hiperbaric solution of ropivacaine for spinal anesthesia. Br J Anesth. 2005;94:107-11.

14. Eid EA, Alsaif F. Plain versus hyperbaric ropivacaine for spinal anesthesia in cirrhotic patients undergoing anorectal surgery. AJAIC. 2007;10:11-8.

15. Kallio H, Snall EVT, Tuomas CA, Rosenberg $\mathrm{PH}$. Comparison of hyperbaric and plain ropivacaine $15 \mathrm{mg}$ in spinal anaesthesi 
for lower limb surgery. $\mathrm{Br} \mathrm{J}$ Anesth. 2004;93(5):664-9.

16. Khaw KS, Kee WN, Wong M, Ng F, Lee A. Spinal ropivacaine for cesarean delivery, a comparison of hyperbaric and plain solutions. Anesth Analg. 2002;94:680-5.

17. Kararmaz A, Kaya S, Turhanoglu S, Ozyilmaz MA. Low dose bupivacainefentanyl spinal anaesthesia for transurethral prostatectomy. Anaesthesia. 2003;58:526-30.

18. Kuusniemi KS, Pihlajamaki KK, Pitkanen MT, Helenius HY, Kirvela OA. The use of bupivacaine and fentanyl for spinal anesthesia for urologic surgery. Anesth Analg. 2000;91:1452-6.

19. Azar I. Transurethral resection of prostate. Dalam: Malhotra V, penyunting. Anesthesia for renal and genito-urologic surgery. New York: McGraw-Hill; 1996. hlm. 93-109.

20. Labbene I, Lamine K, Gharsallah H, Jebali A, Adhoum A, Ghozzi S, dkk. Spinal anesthesia for endoscopic urological surgery - Low dose vs varying doses of hyperbaric bupivacaine. ME J Anesth. 2007;19(2): 369-84.

21. Shreideh ZF, Kelani MT, Al-Ajlouni SM.
Spinal anesthesia for transurethral surgery, a comparative study between heavy bupivacaine $0.5 \%$ and $2 \%$ lignocaine plus low dose fentanyl. JRMS. 2002;9(2):43-6.

22. Astra Zeneca. Product monograph. Naropin (ropivacaine HCL). Aus Par Astra Zeneca Group; 2011.

23. Butterworth. J. Local anesthetics. Dalam: Morgan GE, Mikhail MS, penyunting. Clinical anesthesiology. Edisi ke-4. New York: McGraw-Hill Co; 2006. hlm. 263-75.

24. Galal MA, Younis MM, Ibrahim AY, Ghobrial $\mathrm{BB}$, Khamis AM. Intrathecal hyperbaric ropivacaine versus bupivacaine in TURP [tesis]. Cairo: Ain Shams University Cairo; 2007.

25. Malinovsky JM, Charles F, Kick O, Lepage JY, Malinge M, Cozian A, dkk. Intrathecal anesthesia: ropivacaine versus bupivacaine. Anesth Analg. 2000;91: 1457-60.

26. Collins VJ. Spinal anaesthesia principles. Dalam: Graeme ML, Colin MC, Tony W, penyunting. Principles of anesthesiology general and regional anaesthesia. Edisi ke4. Pennsylvania: William and Wilkins Co; 1996. hlm. 1445-92. 